\title{
The performance of Agricultural science and technology transformation Fund of different Technical Fields ${ }^{1}$
}

\author{
Shen Qiang* Xu Li-li Wang Jun-qiang Yang Wei-min \\ College of urban \& rural development BUA, Beijing, China.
}

Keywords: Agricultural scientific and technological transformation Fund; Performance evaluation; Comprehensive assessment; Technical Fields

Abstract: Based on perfecting the performance evaluation index system of Agricultural scientific and technological achievements transformation Fund. In this paper, we evaluated the performance of Agricultural scientific and technological achievements transformation Fund in different technical fields during the "11th five-year plan" using comprehensive evaluation method. Results shows: Though highest the composite performance index of the planting industry in the ten different technical fields, lowest the average composite performance index of transformation Fund, compared with the composite performance index in 2006, the index of Plant protection industry and Agricultural resources efficient use have been improved, however, lowest-ranked in during the "11th five-year plan".

\section{Introduction}

Agricultural science and Agricultural technology is the important support of agriculture and the rapid development of rural economic, and give a major push to the realization of historic leap from the food and clothing to the well-off of the rural overall in China, Although fruitful in agriculture scientific and technological fruits Along with the increase in agricultural scientific and technological, however, the transformation of agricultural scientific research achievements to productive forces hindered because of a serious shortage of resource allocation of transformation long-term, and become the main limiting factors of agricultural productivity of rapid development of agricultural science and technology, different periods of agriculture, rural development, fields of technology of agricultural scientific and technological achievements transformation are supported, since set up of the agricultural scientific and technological achievements transformation fund in 2001,

Along with the increase in agricultural science and technology, how to realize the effective management, improve the operational efficiency of the transformation of funds and expand transformation efficiency are concerns for profit related and scholars, especially the management entities, The research about the fund of the agricultural scientific and technological achievements transformation focused on the policy formulation at present, including the transformation efficiency of funds(Tan Hua, Ni Jia, 2010; MA Wen-guang, ZOU Yi-xing, 2012), the capital management mechanism(Tan Hua, Ni Jia, 2010; MA Wen-guang, ZOU Yi-xing, 2012) operating model of the funds(Yin Xi-guo, Li Lei, 2009; Tan Hua, Wang Kai-yi, 2010) and the evaluation index system of funds performance(DAI Yuan-kun, WANG Qing-ping, 2013) have been thoroughly researched, And some feasible suggestions were proposed. However, these researches are centered on the funds itself, and Economic, social and environmental benefits of the transformation funds have not been investigated.

\footnotetext{
1 This work is partially supported by the social sciences planning project of the Education Commission of Beijing: Research on the mechanism optimization sy stem of the transformation of agricultural scientific and technological achievements in Beijing B ased on the knowledge sharing.
} 
Agricultural scientific and technological achievements includes different Technical Fields, different Technical Fields are supported by transformation funds during the development period of the agriculture in china. For example, technological achievements in Farming and processing, agricultural equipment were transformated first during in 2006-2007, Food production, development of modern agriculture and related industries were Developed priority in2009, however, in 2009, Rural informationization, biological breeding, food and agricultural products processing have become a priority with the investment of the transformation funds in 2010 according to the guid ance of rural science and technology work in "11th five-year plan".

Based on the researches above, taking the data of projects approved by the Project supervision companies organized by the rural technology development center in China in 2006-2010, evaluating the agricultural scientific and technological achievements transformation fund performance of different technical fields in china using the comprehensive evaluation method, after building and perfecting the performance evaluation index system.

\section{Establishment of the evaluation index system and data processing}

\section{Establishment of the evaluation index system}

We adjusted the evaluation index system for primary using expert consultation, according to the evaluation goal of the agricultural scientific and technological achievements transformation fund performance, and the characteristics of Agricultural scientific and technological achievements transformation and influence factors, 4 broad categories, 9 subcategories, 27 individual indicators were composed the evaluation index system, just as discribled in table 1.

Table 1. Evaluation index system and the weight of performance of agricultural scientific and technological achie vements transformation fund in China

\begin{tabular}{|c|c|c|c|}
\hline $\begin{array}{l}\text { first-level } \\
\text { index }\end{array}$ & $\begin{array}{l}\text { second-level index } \\
\text { (The weight of the } \\
\text { first-level index) }\end{array}$ & $\begin{array}{l}\text { third-level index } \\
\text { (The weight of the second-level index) }\end{array}$ & $\begin{array}{c}\text { Weight of the } \\
\text { third-level } \\
\text { index }\end{array}$ \\
\hline \multirow{3}{*}{$\begin{array}{l}\text { Input of } \\
\text { project } 0.15\end{array}$} & Objective of project 0.24 & contents of objectives 1.0 & 0.03 \\
\hline & decision of project 0.3 & Decision-making process 1.0 & 0.0454 \\
\hline & allocation of funds 0.5 & regulatory compliance of the funds 1.0 & 0.075 \\
\hline \multirow{2}{*}{$\begin{array}{l}\text { process of } \\
\text { project } 0.10\end{array}$} & available of funds 0.5 & available rates of funds 1.0 & 0.05 \\
\hline & $\begin{array}{l}\text { organization and } \\
\text { implementation } 0.5\end{array}$ & management system 1.0 & 0.05 \\
\hline \multirow{12}{*}{$\begin{array}{l}\text { Output of the } \\
\text { project } 0.35\end{array}$} & \multirow{12}{*}{ Output 1.0} & Number of new varieties development 0.1 & 0.0354 \\
\hline & & $\begin{array}{l}\text { Number of testing demonstration zone } \\
\text { Establishment }\end{array}$ & 0.035 \\
\hline & & Number of new technology Promotion 0.09 & 0.0315 \\
\hline & & Number of new procedure Promotion 0.09 & 0.0315 \\
\hline & & Number of new equipment Promotion 0.09 & 0.0315 \\
\hline & & Number of new material Promotion 0.09 & 0.0315 \\
\hline & & Number of pilot line Set up 0.08 & 0.028 \\
\hline & & Number of production line Set up 0.08 & 0.028 \\
\hline & & Number of Patent authorized 0.07 & 0.0245 \\
\hline & & number of software copyright registration 0.07 & 0.0245 \\
\hline & & number of Published papers and reports 0.07 & 0.0245 \\
\hline & & number of Published works 0.07 & 0.0245 \\
\hline \multirow{10}{*}{$\begin{array}{l}\text { Effect of } \\
\text { project } 0.4\end{array}$} & \multirow{4}{*}{ economic benefit 0.4} & revenues from Product sales(Million) 0.3 & 0.048 \\
\hline & & revenues from technologies (Million) 0.2 & 0.032 \\
\hline & & consolidated net earning (Million) 0.25 & 0.04 \\
\hline & & Total amount of pay (Million) 0.25 & 0.04 \\
\hline & \multirow{4}{*}{ social benefit 0.4} & adding jobso.25 & 0.04 \\
\hline & & number of farmers Drive 0.4 & 0.064 \\
\hline & & $\begin{array}{l}\text { number of the talents training during the run } \\
\text { time0.15 }\end{array}$ & 0.024 \\
\hline & & number of training courses during the run time 0.2 & 0.032 \\
\hline & \multirow{2}{*}{ ecological benefits 0.2} & $\begin{array}{l}\text { Impact on the utilization of natural resources } \\
\text { rationally } 0.5\end{array}$ & 0.04 \\
\hline & & $\begin{array}{l}\text { Improvement of the agricultural ecological } \\
\text { environment and ecological benefits } 0.5\end{array}$ & 0.04 \\
\hline
\end{tabular}

\section{Data processing}

We divided the qualitative indexs into five grades and scored as follows: superior $(90,100)$, $\operatorname{good}(70,90)$, middle(70,60), low(60,40), bad(0,40), including the contents of objectives, 
decision-making process, regulatory compliance of the funds, management system, impact on the utilization of natural resources rationally and improvement of the agricultural ecological environment and ecological benefits. Then the standard score can be got using Comprehensive Evaluation based on the questionnaire on management of the fund and so on. Finally, the data of all of the quantitative indexes were standardization processing using extreme:

$$
\hat{X}_{i}=\frac{X_{i}-X_{\min }}{X_{\max }-X_{\min }} \times 100
$$

\section{Weights of the indexes}

The premise of the Comprehensive Evaluation, weights of the indexes indicate the influence of each index on population, so the weights of the indexes must be scientifical and reasonable. In this paper, both of the Delphi method and Hierarchical weighted are employed to avoid the influence of subjective factors of Subjective values method and instability of the objective method, just like the Data processing, the weights are achieved by questionnaire on about 30 Senior Experts, and relative deviation was employed to test the accuracy of expert's empowerment,

$$
\delta_{i k}=\frac{m_{i k}-m_{i}}{\max \left|m_{i k}-m_{i}\right|}
$$

Where $i=1,2, \cdots$, and $k$ represents the number of the Experts, so $k=1,2, \ldots, 30$, we denoted the weight of the indexes given by the number $k$ expert at $i$ times $m_{i k}$, so $m_{i}=\frac{1}{k} \sum_{k=1}^{30} m_{i k}$ is the average of the weights given at $i$ times all of the experts, After four times empowerment by the experts, and the accuracy of empowerment:

$$
S_{4}=\sqrt{\frac{1}{30} \sum_{i=1}^{4}\left(m_{i k}-m_{i}\right)^{2}}=92.42 \%
$$

so final weight of the indexes are the average of weights given at 4 times all of the experts.

\section{Comprehensive evaluation}

The Comprehensive value of the agricultural scientific and technological achievements transformation fund performance can be achieved after weighted the standard score of every indexs:

$$
C_{f t}=\sum_{i}^{21} \hat{X}_{i f t} \cdot W_{i}, \quad C_{t}=\sum_{i}^{21} \hat{X}_{i t} \cdot W_{i}
$$

$C_{t}$ represents the evaluation value of agricultural scientific and technological achievements transformation fund performance in China in $t$ (2006-2010) year, and we denoted the evaluation value of agricultural scientific and technological achievements transformation fund performance in $f$ technologies field in $t(2006-2010)$ year $C_{f t}, X_{i f t}$ and $W_{i}$ represents the standardized value and weight of index $i$ respectively. Considering all the projects have been approved, The final performance evaluation value are given as follows:

$$
C_{f t}^{\prime}=0.4 C_{d t}+60, C_{t}^{\prime}=0.4 C_{t}+60
$$




\section{Comprehensive evaluation value calculation}

The agricultural transformation of scientific and technological achievements approved in differernt technologies fields duiring "11th five-year plan" period are given in table2, and comprehensive value of agricultural scientific and technological achievements transformation fund performance in different technical fields are given in table3.

Table 2. Distribution of the agricultural scientific and technological achievements transformation in different technical fields duiring "11th fi ve-year plan" period

\begin{tabular}{lcccc}
\hline technical fields & Number of projects & ratio & number of funds & ratio \\
\hline Planting industry & 504 & $36.26 \%$ & 30595 & $36.07 \%$ \\
Agriculture Production Industry & 233 & $16.76 \%$ & 14805 & $17.45 \%$ \\
Animal husbandry & 134 & $9.64 \%$ & 6320 & $7.45 \%$ \\
Forestry & 106 & $7.63 \%$ & 7700 & $9.08 \%$ \\
Biotechnology products & 65 & $4.68 \%$ & 3850 & $4.54 \%$ \\
Agricultural equipment & 92 & $6.62 \%$ & 5750 & $6.78 \%$ \\
Aquaculture & 91 & $6.55 \%$ & 5905 & $6.96 \%$ \\
Agricultural information technology & 38 & $2.73 \%$ & 2240 & $2.64 \%$ \\
Plant protection & 27 & $1.94 \%$ & 1790 & $2.11 \%$ \\
High efficiency use of Agricultural resources & 100 & $7.19 \%$ & 5865 & $6.91 \%$ \\
\hline
\end{tabular}

Table 3. The comprehensive value of agricultural scientific and technological achievements transformation fund performance in different technical fields (2006-2010).

\begin{tabular}{lccccccc}
\hline technical fields & $\mathbf{2 0 0 6}$ & $\mathbf{2 0 0 7}$ & $\mathbf{2 0 0 8}$ & $\mathbf{2 0 0 9}$ & $\mathbf{2 0 1 0}$ & Average & $\begin{array}{c}\text { Performance index } \\
\text { of Unit funds }\end{array}$ \\
\hline Planting industry & 92.24 & 88.56 & 90.05 & 91.14 & 90.53 & 90.50 & 0.0030 \\
Agriculture Production Industry & 82.19 & 75.91 & 80.12 & 80.08 & 81.78 & 80.02 & 0.0054 \\
Animal husbandry & 80.36 & 72.89 & 69.40 & 75.89 & 76.54 & 75.02 & 0.0119 \\
Forestry & 77.06 & 73.52 & 71.36 & 71.40 & 71.55 & 72.98 & 0.0095 \\
Biotechnology products & 74.41 & 75.31 & 70.28 & 71.29 & 72.00 & 72.66 & 0.0189 \\
Agricultural equipment & 74.28 & 76.31 & 70.79 & 70.79 & 73.94 & 73.22 & 0.0127 \\
Aquaculture & 74.02 & 72.00 & 68.94 & 68.85 & 71.54 & 71.07 & 0.0120 \\
Agricultural information technology & 71.46 & 75.02 & 68.62 & 73.03 & 71.39 & 71.90 & 0.0321 \\
$\begin{array}{l}\text { Plant protection } \\
\text { High efficiency use of Agricultural } \\
\text { resources }\end{array}$ & 71.19 & 71.43 & 70.10 & 71.81 & 73.84 & 71.67 & 0.0400 \\
\hline & 70.90 & 69.04 & 71.45 & 73.63 & 73.31 & 71.67 & 0.0122 \\
\hline
\end{tabular}

\section{Conclusion}

Based on the evaluation of the performance of agricultural scientific and technological achievements transformation fund in different technical fields, the result shows:

First, due to the planting industry development is the important content of agricultural economic development, the agricultural scientific and technological achievements transformation fund project also highlights the "steady food supply, increased stamina". The investment of agricultural scientific and technological achievements transformation fund in the field of planting technology than other fields. From persective of the comprehensive index of agriculture scientific and technological achievements transformation fund performance during 2006-2010, higherest of the comprehensive index of transformation fund performance of Planting technology, and the mean Comprehensive performance index is 90.50 for five years, followed by agricultural products processing technical field, and the mean Comprehensive performance index is 80.02 for five years, though the 
Comprehensive performance indexs of animal husbandry, forestry, agriculture equipment are in the top, still lower than the average indexs of all technical fields.

Second, From persective of change of the comprehensive index of agriculture scientific and technological achievements transformation fund performance during 2006-2010, though lowest ranked of the plant protection and high efficiency use of Agricultural resources, however, the comprehensive indexs in the two fields rised $3.40 \%$ and $3.73 \%$ respectively campared with 2006. and the indexs in other fields decreased in 2006-2010.

Finally, Combined with the distribution of agricultural scientific and technological achievements transformation fund projects approved during the "11 th five-year plan"in different technical fields. Higherest of the performance index of Unit funds in plant protection, and then is the performance index of Unit funds in Agricultural information technology, just as discribled above, higherest of the performance index of agricultural scientific and technological achievements transformation fund in planting technology, but the performance index of Unit funds is lowest, Only 0.0030.

\section{References}

[1] Tan Hua, Ni Jia. Analysis on Current Status and Effect of the Agricultural Science and Technology Achievements Transformation Funds Project [J]. Management of Agricultural Science and Technology. 2010(04): 25-29.

[2] MA Wenguang, ZOU Yixing, YAN Jianhua, GUO Hong. Analysis on Effect of the Agricultural Science and Technology Achievements Transformation Funds Project in Sichuan Province [J]. Science and Technology Management Research. 2012(10): 91-94.

[3] WANG Jinghua, JIA Jingdun. Research on Agricultural Scientific and Technological Achievements Projects Management Mechanism Innovation [J]. Science and Technology Management Research. 2012(17): 125-127.

[4] Wang Jing-hua, Ding Zi-li, Ma Hong-yi, Zhong Chun-yan. Thought and Countermeasures about Performance Management of Transformation Found for Agricultural Scientific and Technological Achievements [J]. Science \& Technology Progress and Policy. 2013(03): 22-24.

[5] Yin Xi-guo, Li Lei, Zhang Yang. Innovation Analysis on the Operational Mode of Transformational Fund of Agricultural Scientific and Technological Achievements in China [J]. Journal of Anhui Agricultural Sciences. 2009(06): 2721-2723.

[6] Tan Hua, Wang Kaiyi, Liu Zhongqiang. Research on Operation Mechanism of Agricultural Science and Technology Achievements Transformation Fund Project [J]. Forum on Science and Technology in China. 2010(07): 136-141.

[7] DAI Yuan-kun, WANG Qing-ping. Study on Performance Evaluation Index System of Agricultural Science and Technology Achievements Transformation Funds [J]. Journal of Anhui Agricultural Sciences. 2012(08): 4966-496. 